\title{
Volatile Profile, Pigment Content, and In Vitro Radical Scavenging Activity of Flower, Thyme, and Fir Honeys Produced in Hellas
}

\author{
Ioannis K. Karabagias", Elpida Dimitriou, Evangelia Halatsi and Christos Nikolaou
}

Laboratory of Food Chemistry, Department of Chemistry, University of Ioannina, Ioannina 45110, Greece

Correspondence to:

Ioannis K. Karabagias

Laboratory of Food Chemistry

Department of Chemistry, University of Ioannina

Ioannina 45110, Greece

E-mail: ikaraba@cc.uoi.gr

Received: June 27, 2017

Accepted: August 14, 2017

Published: August 21, 2017

Citation: Karabagias IK, Dimitriou E, Halatsi, E, Nikolaou C. 2017. Volatile Profile, Pigment Content, and In Vitro Radical Scavenging Activity of Flower, Thyme, and Fir Honeys Produced in Hellas.J Food Chem Nanotechnol 3(3): 98-104.

Copyright: (c) 2017 Karabagias et al. This is an Open Access article distributed under the terms of the Creative Commons Attribution 4.0 International License (CC-BY) (http:// creativecommons.org/licenses/by/4.0/) which permits commercial use, including reproduction, adaptation, and distribution of the article provided the original author and source are credited.

Published by United Scientific Group

\begin{abstract}
The philosophy of the present work was to investigate the volatile profile, pigment content, and in vitro radical scavenging activity of Hellenic honeys, using aqueous honey solutions. Twenty-one honey samples representing flower, thyme and fir honeys were donated from professional beekeepers during two consecutive harvesting years, from three different regions in Hellas.

Volatile profile was estimated using headspace solid phase micro extraction coupled to gas chromatography/mass spectrometry (HSPME-GC/MS). For semi-quantification purposes the internal standard method was used. Pigment content along with the in vitro radical scavenging activity was determined using spectrophotometric methods.

Results showed that the twenty-one honeys analyzed exhibited variations in volatile profile, pigment content and antioxidant activity depending on the floral source $(p<0.05)$. Honey aroma was found to be the outcome of the combination of different class compounds, namely: carboxylic acids, alcohols, aldehydes, ketones, benzene derivatives, etc. The most pronounced aromas were recorded for flower honey, whereas fir honey possessed the highest pigment content and radical scavenging activity $(p<0.05)$. In addition, specific volatiles (2-hydroxy-benzoic acid methyl ester, alpha-pinene, para-cymene, and delta-3-carene) were perfectly correlated (Pearson's correlation coefficient $r=1$ ) with radical scavenging activity $(p<0.01)$.
\end{abstract}

The present results enhance the quality control and authenticity of Hellenic honey and may be of great interest to a wider audience including: consumers, honey industry, and honey researchers, at an international level.

\section{Keywords}

Honey, Aroma, Pigment content, Antioxidant activity, Authenticity

\section{Abbreviations}

HS-SPME: Headspace solid phase micro extraction; GC/MS: Gas chromatography/Mass spectrometry; DPPH: 2,2-Diphenyl-1-picrylhydrazyl; RSA: Radical scavenging activity; VOCs: Volatile organic compounds; 2-(OH)BAME: 2-hydroxy-benzoic acid methyl ester; DAEE: Decanoic acid ethyl ester; IS: Internal standard

\section{Introduction}

"Complex as the universe", could be a few words to describe honey, the product of Apis mellifera honeybees. Nectar from different flowers or honeydew secretions 
from conifer trees are all well exploited by honeybees for the production of honey.

Honeybee honey is a highly concentrated solution of a complicated mixture of several sugars. Water represents the second major constituent, whereas there are small amounts of other components, such as: minerals, proteins, vitamins, organic acids, flavonoids, phenolic acids, enzymes, and numerous volatile organic compounds (VOCs).

VOCs in honey originate from different biosynthetic pathways and contribute to the development of honey distinguishable aroma, which is greatly affected by botanical and geographical origin $[1,2]$. Despite their presence in low proportions, VOCs could contribute to biomedical activity of honey due to their natural radical scavenging activity potential [1].

As a multi plant-based foodstuff, honey contains certain bioactive compounds (phenolic acids, flavonoids, carotenoids, enzymes, free amino acids, ascorbic acid, etc), as aforementioned, that may have specific functions within the human body which helps maintain and promote health or prevent the body from several diseases [3, 4].

On the other hand, there is a great tendency for simple, fast, non-expensive, and eco-friendly methodologies to be applied on the quality control of agricultural products [1].

HS-SPME/GC-MS is a fast, simple and well developed technique that may provide useful information on the headspace aroma of untreated or low treated foodstuffs, while the volatile profile of the determined compounds is closely associated with that of sensory perception $[1,5,6]$.

DPPH method serves as a good monitor of the in vitro radical scavenging activity of antioxidant compounds being present in plant-based food matrices [7]. It may be characterized as a fast, reproducible spectrometric technique that has been used to estimate, among others, the radical scavenging activity of water- soluble antioxidants $[8,9]$. It should also be stressed that, the in vitro radical scavenging activity of honey, depends greatly on its botanical origin $[8,9]$.

Based on the afore mentioned, the purpose of the present study was to evaluate volatile profile, pigment content and antioxidant activity of flower, thyme and fir honeys aqueous solutions, using less organic solvents and a low amount of untreated honey sample, by application of simple and fast modern techniques. To the best of our knowledge, there are limited research studies that enhance the potential of watersoluble antioxidants of different honey types produced in the Hellenic zone [9] this constituting a fair novelty.

\section{Materials and Methods}

\section{Honey samples}

Twenty-one honey samples were collected; 7 flower honeys from Samos Island, 12 thyme (Thymus capitatus (L.)) from Kos Island, and 2 fir honeydew honeys from Aitolokarnania region, during the harvesting years 2011 and 2012, from professional beekeepers. All honey samples were stored in glass containers and maintained at $4 \pm 1{ }^{\circ} \mathrm{C}$ before analysis.

\section{Reagents and solutions}

Benzophenone was purchased from Sigma-Aldrich (Germany). Sodium chloride $(\mathrm{NaCl})$, methanol, and acetate buffer $\left(\mathrm{CH}_{3} \mathrm{COONa}^{*} 3 \mathrm{H}_{2} \mathrm{O}\right)$ were purchased from Merck (KGaA, 64271, Darmstadt, Germany). 2,2-Diphenyl-1picrylhydrazyl [DPPH'], was purchased from Sigma-Aldrich (Germany). All aqueous honey solutions were prepared using distilled water.

\section{HS-SPME-GC/MS analysis}

Headspace volatile compounds were extracted from honey, using a divinyl benzene/carboxen/polydimethylsiloxane (DVB/ CAR/PDMS) fiber 50/30 $\mu \mathrm{m}$ (Supelco, Bellefonte, PA, USA). The fiber was conditioned by following the manufacturer's recommendations, prior analysis. Honey samples of $2 \mathrm{~g}$ dissolved in $2 \mathrm{~mL}$ of distilled water containing $0.20 \mathrm{~g} \mathrm{NaCl}$ and $20 \mu \mathrm{L}$ of internal standard (benzophenone, $100 \mu \mathrm{g} / \mathrm{mL}$ ), were placed in $15 \mathrm{~mL}$ screw-cap vials equipped with PTFE/ silicone septa. Each vial was maintained at $45{ }^{\circ} \mathrm{C}$ in a water bath under stirring at $600 \mathrm{rpm}$ for the headspace extraction. A cross-shaped PTFE-coated magnetic stirrer (diameter $10 \mathrm{~mm}$ ) (Semadeni, Ostermundigen-Bern, Switzerland) was placed inside the vials. The sample preparation conditions were: 15 min equilibration time, $30 \mathrm{~min}$ sampling time, $4 \mathrm{~mL}$ sample volume and $45{ }^{\circ} \mathrm{C}$ water bath temperature. The temperature of $45^{\circ} \mathrm{C}$ was chosen in order to avoid enzymatic activity and keep at minimum the formation of thermal artifacts like furan derivatives, furfural, etc.

Honey samples analyzed, were prepared daily prior to HSSPME-GC/MS analysis. Blank runs were carried out before sample analysis to make sure that there was no contamination that could cause memory effects, and thus, the collection of false results. Each sample was run in duplicate $(n=2)$.

\section{Identification and semi-quantification of volatile compounds}

\section{GC/MS instrumentation and conditions}

A GC unit (Agilent 7890 A) coupled to a MS detector (Agilent 5975) was used to analyze the prepared honey solutions. A DB-5MS (cross-linked 5\% PH ME siloxane) capillary column, having dimensions of $60 \mathrm{~m}$ x $320 \mu \mathrm{m}$ i.d., $\mathrm{x}$ $1 \mu \mathrm{m}$ film thickness, was used, with helium as the carrier gas (purity 99.999\%), at $1.5 \mathrm{~mL} / \mathrm{min}$ flow rate. The temperature for the injector and MS-transfer line were maintained constant at $250{ }^{\circ} \mathrm{C}$ and $270^{\circ} \mathrm{C}$, respectively. The oven temperature was held at $40{ }^{\circ} \mathrm{C}$ for $3 \mathrm{~min}$, and was further increased to $260{ }^{\circ} \mathrm{C}$ having a rate of $8{ }^{\circ} \mathrm{C} / \mathrm{min}$, for $6 \mathrm{~min}$. Electron impact mass spectra were recorded at the mass range of 50-550. The ionization energy of the electron ionization system was $70 \mathrm{eV}$ [2].

\section{Mass spectral data processing}

The identification of compounds was achieved using the Wiley 7, NIST 2005 mass spectral library. For the determination of linear retention indices a mixture of $\mathrm{n}$-alkanes $\left(\mathrm{C}_{8}-\mathrm{C}_{20}\right)$ dissolved in $\mathrm{n}$-hexane, was employed. The standard mixture was purchased from Supelco (Bellefonte, 
PA, USA). Calculation of retention time indices was carried out for components eluting between n-octane and n-eicosane. Benzophenone $(\mathrm{m} / \mathrm{z}=182)$ was chosen as an internal standard since it did not naturally occur in any of the isolated compounds [10]. Volatile compounds having $\geq 85 \%$ similarity with the Wiley mass spectral library were tentatively identified using GC-MS spectra. For semi-quantification, compound content was expressed as $\mu \mathrm{g} / \mathrm{kg}$ based on the ratio:

Volatiles $(\mu g / \mathrm{kg})=\left(\frac{\text { peak area of analyte }}{\text { peak area of internal standard }}\right)$----------Eq.

In vitro estimation of radical scavenging activity (\%RSA) of Hellenic honeys

Preparation of [ $\left.\mathrm{DPPH}^{*}\right]$ standard solution

The free radical [DPPH$\left.{ }^{*}\right]$ standard solution was prepared according to Karabagias et al. [9].

Preparation of [ $\left.\mathrm{DPPH}^{\bullet}\right]$ calibration curve

This step is mandatory, in order to estimate the \%decrease in $\left[\mathrm{DPPH}^{\cdot}\right]$ free radical absorbance (\%RSA), \% decrease in $\left[\mathrm{DPPH}^{*}\right]$ free radical concentration, $\%\left[\mathrm{DPPH}^{*}\right]$ remaining of the mixture obtained by the addition of honey aqueous solution, when the reaction between free radical and honey antioxidant components reaches plateau (steady state). A calibration curve of different [ $\left.\mathrm{DPPH}^{-}\right]$concentrations, covering the range of 0-40 $\mathrm{mg} / \mathrm{L}$, versus the respective absorbance, was prepared according to Karabagias et al. [9].

\section{Calculation of \%RSA of Hellenic honeys}

The in vitro radical scavenging activity of aqueous honey solutions was estimated using the $\left[\mathrm{DPPH}^{\cdot}\right]$ assay according to the method of Karabagias et al. [9]. The reaction was completed in $4 \mathrm{~h}$ (plateau). The absorbance at the plateau for each sample was measured at $517 \mathrm{~nm}$ using a UV/VIS Spectrometer (PerkinElmer, Lambda 25, USA).

Radical scavenging activity was calculated using the following equation:

$\% R S A=\left(\frac{\mathrm{A}_{\mathrm{o}}-\mathrm{A}_{\mathrm{t}}}{\mathrm{A}_{\mathrm{o}}}\right) \times 100$------------ Eq. (2),

Taking into account that: $A_{0}$ is the initial absorbance of the $\left[\mathrm{DPPH}^{*}\right]$ free radical standard solution and $\mathrm{A}_{\mathrm{t}}$ is the absorbance of the remaining [ $\left.\mathrm{DPPH}^{*}\right]$ free radical after the reaction with aqueous honey solution antioxidants, at steady state. Each sample was run in triplicate $(n=3)$. Methanol and acetate buffer $(2: 1, \mathrm{v} / \mathrm{v})$ served as the blank [9].

Determination of pigment content of Hellenic honeys: Net absorbance $\mathrm{ABS}_{450-720}$

Honey color is the outcome of a combination of numerous pigments with antioxidant properties [8]. Such pigments (carotenoids, flavonoids, etc.) are associated with honey floral origin. Pigment content, may be defined as the difference between spectrometric absorbance at 450 and 720 $\mathrm{nm}\left(\mathrm{ABS}_{450-720}\right)$ and was used to evaluate the contribution of honey colored phytochemical to the total antioxidant capacity of honey aqueous solution. Aqueous honey solutions were prepared according to Karabagias et al. [9]. Results were expressed as absorbance units (mAU).

\section{Statistical analysis}

Mean values of the investigated parameters were subjected to T-test in order to test the existence of significant variations with respect to honey botanical origin $(p<0.05)$. Pearson's correlation coefficient ( $r$ ), was computed to estimate any kind of correlations between the investigated parameters at the confidence level $p<0.05$. Statistical treatment of data was performed using the SPSS v.22.0 statistics software [9].

\section{Results and Discussion}

\section{Volatile profile of Hellenic honeys}

The aroma of Hellenic honey is owed to the combination of numerous compounds including: alcohols, aldehydes, benzene derivatives, esters, hydrocarbons, ketones, norisoprenoids, etc. Volatile fraction of Hellenic honeys proved to be dependent on botanical origin (Tables 1-3). In particular, flower honeys possessed a richer volatile pattern compared to thyme or fir honeys. Respective total volatile content $(\mu \mathrm{g} / \mathrm{kg})$, calculated from the average of each compound presented in Tables 1-3, followed the order: flower honey $(55.19 \mu \mathrm{g} / \mathrm{kg})>$ thyme honey $(31.24 \mu \mathrm{g} / \mathrm{kg})>$ fir honey $(24.11 \mu \mathrm{g} / \mathrm{kg})$. A typical gas chromatogram of fir honey from the region of Aitolokarnania is shown in Figure 1.

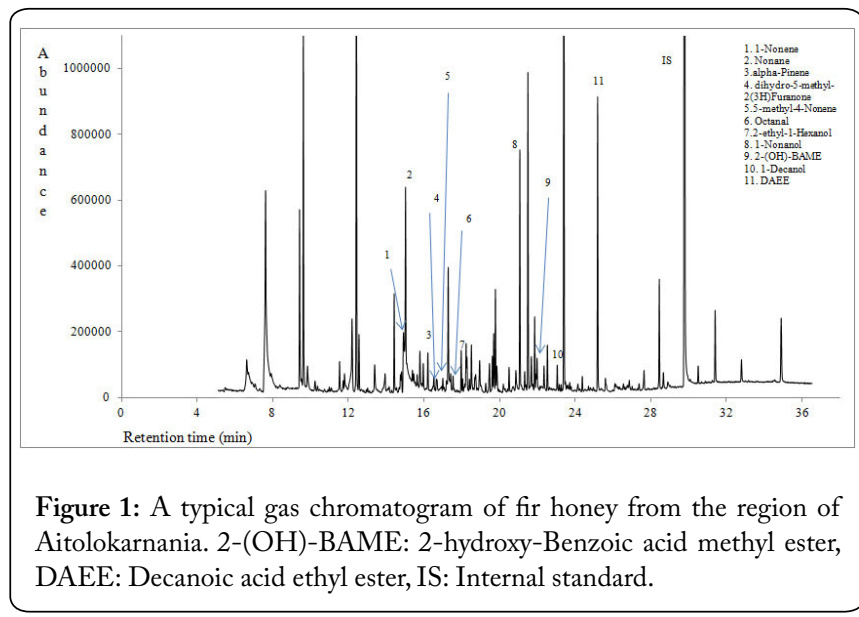

Numerous volatile compounds identified in the present study such as: carboxylic acids (acetic acid, 2-methyl-propanoic acid, pentanoic acid, decanoic acid), alcohols (2-ethyl-1hexanol,1-nonanol,1-decanol, etc.), linear aldehydes (heptanal, octanal, nonanal, decanal, etc.), benzene derivatives (methylbenzene, 1,3-dimethyl-benzene, 1-methyl-4-(1-methylethyl)benzene, 2,2-diethoxyethyl-benzene, benzeneacetonitrile, benzenemethanol, benzeneethanol, etc.), esters (formic acid ethyl ester, hexanoic acid ethyl ester, octanoic acid ethyl ester, nonanoic acid ethyl ester, decanoic acid ethyl ester, etc.), hydrocarbons (octane,1-nonene, nonane, 5-methyl-4-nonene, undecane), ketones (1-2-furanyl-ethanone), norisoprenoids (2,6,6-trimethyl-2-cyclohexene-1,4-dione), terpenoids (alpha-pinene, 2-beta-pinene, dL-limonene, etc.), and furan derivatives (2,5-diethyltetrahydro-furan, 3-phenyl-furan2,5dimethyl-3-ethyl-4-acetyl-furan), have been reported 
previously to enhance the volatile profile of several honey types produced in different countries $[2,5,6,10,11-15]$.

In particular, acetic, 2-methyl-propanoic, pentanoic, and decanoic acids were identified only in thyme honey samples

Table 1: Volatile compounds (VOCs, $\mu \mathrm{g} / \mathrm{kg}$ ) identified in flower honeys from Samos Island.

\begin{tabular}{|c|c|l|c|c|c|}
\hline RT & KI & \multicolumn{1}{|c|}{ VOCs } & Average & $\pm \mathrm{SD}$ & $\begin{array}{c}\text { Method of } \\
\text { identification }\end{array}$ \\
\hline 12.17 & $<800$ & 1-Octene & 4.67 & 3.47 & $\mathrm{MS}$ \\
\hline 12.40 & 800 & Octane & 95.89 & 81.32 & $\mathrm{MS} / \mathrm{KI}$ \\
\hline 13.37 & 837 & 2-Furancarboxaldehyde & 16.63 & 23.99 & $\mathrm{MS} / \mathrm{KI}$ \\
\hline 14.48 & 879 & 1,3-dimethyl- Benzene & 3.51 & 5.40 & $\mathrm{MS} / \mathrm{KI}$ \\
\hline 14.79 & 892 & 1-Nonene & 2.84 & 1.81 & $\mathrm{MS} / \mathrm{KI}$ \\
\hline 15.00 & 900 & Nonane & 25.56 & 18.71 & $\mathrm{MS} / \mathrm{KI}$ \\
\hline 15.10 & 904 & para-Xylene & 6.72 & 6.67 & $\mathrm{MS} / \mathrm{KI}$ \\
\hline 16.18 & 949 & alpha-Pinene & 39.09 & 25.74 & $\mathrm{MS} / \mathrm{KI}$ \\
\hline 16.86 & 978 & Benzaldehyde & 11.86 & 11.20 & $\mathrm{MS} / \mathrm{KI}$ \\
\hline 17.25 & 994 & Hexanoic acid ethyl ester & 12.17 & 7.82 & $\mathrm{MS} / \mathrm{KI}$ \\
\hline 17.33 & 997 & 2-beta-Pinene & 9.31 & 7.53 & $\mathrm{MS} / \mathrm{KI}$ \\
\hline 17.51 & 1005 & Octanal & 33.14 & 16.06 & $\mathrm{MS} / \mathrm{KI}$ \\
\hline 17.94 & 1025 & delta-3-Carene & 17.34 & 9.40 & $\mathrm{MS} / \mathrm{KI}$ \\
\hline 18.01 & 1028 & 2-ethyl-1-Hexanol & 1.41 & 1.37 & $\mathrm{MS} / \mathrm{KI}$ \\
\hline 18.25 & 1038 & $\begin{array}{l}\text { 1-methyl-4-(1- } \\
\text { methylethyl- Benzene }\end{array}$ & 25.19 & 11.09 & $\mathrm{MS} / \mathrm{KI}$ \\
\hline 18.37 & 1044 & dL-Limonene & 3.47 & 2.50 & $\mathrm{MS} / \mathrm{KI}$ \\
\hline 18.70 & 1059 & Benzeneacetaldehyde & 14.06 & 13.30 & $\mathrm{MS} / \mathrm{KI}$ \\
\hline 19.75 & 1107 & Nonanal & 186.19 & 85.87 & $\mathrm{MS} / \mathrm{KI}$ \\
\hline 20.82 & 1160 & $\begin{array}{l}\text { 2,6,6-trimethyl-2- } \\
\text { Cyclohexene-1,4-dione }\end{array}$ & 1.44 & 1.42 & $\mathrm{MS} / \mathrm{KI}$ \\
\hline 21.04 & 1170 & 1-Nonanol & 18.60 & 15.94 & $\mathrm{MS} / \mathrm{KI}$ \\
\hline 21.47 & 1191 & Octanoic acid, ethyl ester & 46.98 & 16.87 & $\mathrm{MS} / \mathrm{KI}$ \\
\hline 21.82 & 1209 & Decanal & 135.96 & 75.31 & $\mathrm{MS} / \mathrm{KI}$ \\
\hline 21.98 & 1216 & $\begin{array}{l}\text { 2-hydroxy- Benzoic acid } \\
\text { methyl ester }\end{array}$ & 6.49 & 3.75 & $\mathrm{MS} / \mathrm{KI}$ \\
\hline 23.37 & 1290 & Nonanoic acid ethyl ester & 99.28 & 35.97 & $\mathrm{MS} / \mathrm{KI}$ \\
\hline 23.76 & 1311 & Undecanal & 4.23 & 3.02 & $\mathrm{MS} / \mathrm{KI}$ \\
\hline 25.15 & 1389 & Decanoic acid ethyl ester & 63.14 & 17.73 & $\mathrm{MS} / \mathrm{KI}$ \\
\hline 25.56 & 1413 & Dodecanal & 2.33 & 2.06 & $\mathrm{MS} / \mathrm{KI}$ \\
\hline 26.83 & 1489 & $\begin{array}{l}\text { Undecanoic acid ethyl } \\
\text { ester }\end{array}$ & 1.78 & 2.04 & $\mathrm{MS} / \mathrm{KI}$ \\
\hline 26.98 & 1498 & Pentadecane & $\begin{array}{l}\text { Tridecanoic acid ethyl } \\
\text { ester }\end{array}$ \\
\hline 28.41 & $1588 \mathrm{KI}$ \\
\hline 34.87 & 1983 & $\mathrm{MS} / \mathrm{KI}$ \\
\hline & & & & & \\
\hline
\end{tabular}

RT: Retention time (min), KI: Experimental Kovats index values using hydrocarbons being naturally present in honey. Volatile compounds are given with respect to retention time. Average \pm standard deviation values of seven $(\mathrm{N}=7)$ floral honey samples expressed as $\mu \mathrm{g} / \mathrm{kg}$ of honey. Method of identification: MS, identification by comparison with MS data in Wiley 7 NIST 2005 mass spectral library. KI: identification by comparison of Kovats index with the literature cited or included in the Wiley library. Comparison of values using T-test at the confidence level $p<0.05$.
Table 2: Volatile compounds (VOCs, $\mu \mathrm{g} / \mathrm{kg}$ ) identified in thyme honeys from Kos Island.

\begin{tabular}{|c|c|c|c|c|c|}
\hline RT & KI & VOCs & Average & $\pm \mathrm{SD}$ & $\begin{array}{c}\text { Method of } \\
\text { identification }\end{array}$ \\
\hline 5.20 & $<800$ & Formic acid, ethyl ester & 2.50 & 1.72 & MS \\
\hline 7.03 & $<800$ & Acetic acid & 17.50 & 13.42 & MS \\
\hline 7.58 & $<800$ & 2-methyl- Propanenitrile & 4.16 & 3.27 & MS \\
\hline 8.47 & $<800$ & 3-methyl- Butanal & 1.57 & 1.13 & MS \\
\hline 10.81 & $<800$ & 2-methyl- Propanoic acid & 7.16 & 3.38 & MS \\
\hline 11.70 & $<800$ & methyl- Benzene & 14.00 & 8.75 & MS \\
\hline 12.40 & 800 & Octane & 21.57 & 19.92 & $\mathrm{MS} / \mathrm{KI}$ \\
\hline 13.02 & 823 & Pentanoic acid & 12.14 & 8.09 & $\mathrm{MS} / \mathrm{KI}$ \\
\hline 13.26 & 833 & 2-methyl- Butanoic acid & 2.04 & 2.90 & $\mathrm{MS} / \mathrm{KI}$ \\
\hline 13.37 & 836 & 2-Furancarboxaldehyde & 46.05 & 11.82 & $\mathrm{MS} / \mathrm{KI}$ \\
\hline 15.01 & 852 & $\begin{array}{l}\text { 2,5-diethyltetrahydro- } \\
\text { Furan }\end{array}$ & 21.80 & 22.19 & $\mathrm{MS} / \mathrm{KI}$ \\
\hline 15.08 & 903 & Heptanal & 2.11 & 3.93 & $\mathrm{MS} / \mathrm{KI}$ \\
\hline 15.37 & 914 & 1-(2-furanyl)-Ethanone & 1.37 & 1.55 & $\mathrm{MS} / \mathrm{KI}$ \\
\hline 16.18 & 948 & alpha-Pinene & 3.03 & 4.42 & $\mathrm{MS} / \mathrm{KI}$ \\
\hline 16.87 & 977 & Benzaldehyde & 148.23 & 33.08 & $\mathrm{MS} / \mathrm{KI}$ \\
\hline 17.39 & 1000 & Decane & 3.20 & 3.15 & $\mathrm{MS} / \mathrm{KI}$ \\
\hline 17.51 & 1005 & Octanal & 16.48 & 5.56 & $\mathrm{MS} / \mathrm{KI}$ \\
\hline 17.94 & 1025 & delta-3-Carene & 5.32 & 5.42 & $\mathrm{MS} / \mathrm{KI}$ \\
\hline 18.01 & 1027 & 2-ethyl-1-Hexanol & 2.21 & 2.41 & $\mathrm{MS} / \mathrm{KI}$ \\
\hline 18.24 & 1038 & $\begin{array}{l}\text { 1-methyl-4-(1- } \\
\text { methylethyl)- Benzene }\end{array}$ & 18.45 & 7.09 & $\mathrm{MS} / \mathrm{KI}$ \\
\hline 18.39 & 1044 & Benzenemethanol & 2.67 & 2.74 & $\mathrm{MS} / \mathrm{KI}$ \\
\hline 18.71 & 1059 & Benzeneacetaldehyde & 749.68 & 398.87 & $\mathrm{MS} / \mathrm{KI}$ \\
\hline 19.59 & 1100 & Undecane & 3.89 & 4.56 & $\mathrm{MS} / \mathrm{KI}$ \\
\hline 19.75 & 1107 & Nonanal & 36.83 & 21.55 & $\mathrm{MS} / \mathrm{KI}$ \\
\hline 20.21 & 1129 & Benzeneethanol & 93.45 & 33.85 & $\mathrm{MS} / \mathrm{KI}$ \\
\hline 20.71 & 1154 & Benzeneacetonitrile & 63.45 & 31.86 & $\mathrm{MS} / \mathrm{KI}$ \\
\hline 21.47 & 1191 & Octanoic acid ethyl ester & 7.63 & 5.63 & $\mathrm{MS} / \mathrm{KI}$ \\
\hline 21.82 & 1209 & Decanal & 28.31 & 8.88 & $\mathrm{MS} / \mathrm{KI}$ \\
\hline 22.56 & 1248 & 3-phenyl- Furan & 5.28 & 7.74 & $\mathrm{MS} / \mathrm{KI}$ \\
\hline 22.65 & 1253 & $\begin{array}{l}\text { Benzeneacetic acid ethyl } \\
\text { ester }\end{array}$ & 9.02 & 8.65 & $\mathrm{MS} / \mathrm{KI}$ \\
\hline 23.35 & 1288 & $\begin{array}{l}\text { alpha,-ethylidene- } \\
\text { Benzeneacetaldehyde }\end{array}$ & 6.86 & 10.05 & $\mathrm{MS} / \mathrm{KI}$ \\
\hline 23.68 & 1306 & $\begin{array}{l}\text { 2-methyl-5-(1- } \\
\text { methylethyl)- Phenol }\end{array}$ & 4.76 & 5.25 & $\mathrm{MS} / \mathrm{KI}$ \\
\hline 24.06 & 1328 & $\begin{array}{l}\text { 2,2-diethoxyethyl- } \\
\text { Benzene }\end{array}$ & 17.92 & 12.43 & $\mathrm{MS} / \mathrm{KI}$ \\
\hline 24.43 & 1348 & Decanoic acid & 8.73 & 5.07 & $\mathrm{MS} / \mathrm{KI}$ \\
\hline 25.37 & 1401 & beta-Damascenone & 4.48 & 4.03 & $\mathrm{MS} / \mathrm{KI}$ \\
\hline 26.61 & 1475 & $\begin{array}{l}\text { Propanedioic acid, } \\
\text {-ethoxymethylene- } \\
\text { diethyl ester }\end{array}$ & 1.14 & 1.35 & $\mathrm{MS} / \mathrm{KI}$ \\
\hline 27.98 & 1561 & $\begin{array}{l}\text { 2,5-dimethyl-3-ethyl-4- } \\
\text { acetyl-Furan }\end{array}$ & 2.45 & 3.64 & $\mathrm{MS} / \mathrm{KI}$ \\
\hline
\end{tabular}




\begin{tabular}{|l|c|l|c|c|c|}
\hline 28.42 & 1588 & $\begin{array}{l}\text { Dodecanoic acid ethyl } \\
\text { ester }\end{array}$ & 1.38 & 2.38 & MS/KI \\
\hline
\end{tabular}

RT: Retention time (min), KI: Experimental Kovats index values using hydrocarbons being naturally present in honey. Volatile compounds are given with respect to retention time. Average \pm standard deviation values of seven $(\mathrm{N}=15)$ thyme honey samples expressed as $\mu \mathrm{g} / \mathrm{\kappa g}$ of honey. Method of identification: MS, identification by comparison with MS data in Wiley 7 NIST 2005 mass spectral library/ KI, identification by comparison of Kovats index with the literature cited or included in the Wiley library. Comparison of values using T-test at the confidence level $p<0.05$.

from Kos Island. This finding is in conformity with previous works on Italian, Spanish and Hellenic thyme honeys, respectively $[2,5,6,11]$.

2-ethyl-1-hexanol was found in higher amounts $(\mu \mathrm{g} / \mathrm{kg})$ in fir honeys from Aitolokarnania compared to thyme honeys from Kos Island or flower honeys from Samos Island. The same holds for nonanol which was found at a content $(\mu \mathrm{g} /$ $\mathrm{kg}$ ) ca. 3 times fold higher in fir honeys, compared to flower honeys (Table 1 and 3). Finally, decanol was identified only in fir honeys from Aitolokarnania and may be indicative of this particular honey type [2].

Table 3: Volatile compounds (VOCs, $\mu \mathrm{g} / \mathrm{kg}$ ) identified in fir honeys from Aitolokarnania.

\begin{tabular}{|c|l|l|l|l|l|}
\hline RT & KI & \multicolumn{1}{|c|}{ VOCs } & Average & \pm SD & $\begin{array}{l}\text { Method of } \\
\text { identification }\end{array}$ \\
\hline 14.80 & 892 & 1-Nonene & 7.57 & 0.61 & MS/KI \\
\hline 15.01 & 900 & Nonane & 79.19 & 10.16 & MS/KI \\
\hline 16.19 & 949 & alpha-Pinene & 16.97 & 8.44 & MS/KI \\
\hline 16.41 & 959 & $\begin{array}{l}\text { dihydro-5-methyl- } \\
\text { 2(3H)-Furanone }\end{array}$ & 3.36 & 3.33 & MS/KI \\
\hline 16.99 & 982 & $\begin{array}{l}\text { 5-methyl-4-Nonene, } \\
\text { (Z) }\end{array}$ & 19.99 & 24.02 & MS/KI \\
\hline 17.53 & 1005 & Octanal & 30.54 & 37.54 & MS/KI \\
\hline 18.02 & 1028 & 2-ethyl-1-Hexanol & 8.04 & 7.12 & MS/KI \\
\hline 21.07 & 1170 & 1-Nonanol & 53.58 & 13.31 & MS/KI \\
\hline 21.98 & 1216 & $\begin{array}{l}\text { 2-hydroxy- Benzoic } \\
\text { acid methyl ester }\end{array}$ & 10.16 & 4.02 & MS/KI \\
\hline 23.05 & 1273 & 1-Decanol & 10.00 & 2.83 & MS/KI \\
\hline 25.19 & 1389 & $\begin{array}{l}\text { Decanoic acid ethyl } \\
\text { ester }\end{array}$ & 47.80 & 41.30 & MS/KI \\
\hline
\end{tabular}

RT: Retention time (min), KI: Experimental Kovats index values using hydrocarbons being naturally present in honey. Volatile compounds are given with respect to retention time. Average \pm standard deviation values of two $(\mathrm{N}=2)$ fir honey samples expressed as $\mu \mathrm{g} / \mathrm{kg}$ of honey. Method of identification: MS, identification by comparison with MS data in Wiley 7 NIST 2005 mass spectral library KI: identification by comparison of Kovats index with the literature cited or included in the Wiley library. Comparison of values using $\mathrm{T}$-test at the confidence level $p<0.05$.

Octanal, nonanal, and decanal were identified in higher amounts $(\mu \mathrm{g} / \mathrm{kg})$ in flower honeys from Samos Island compared to thyme honeys from Kos Island, or fir honeys from Aitolokarnania. The aforementioned aldehydes have been reported previously to enhance the volatile fraction of Spanish [2, 5, 6, 10], and Hellenic thyme honey [2], or even in Turkish pine honey [16] The lower content of octanal, nonanal and decanal in fir honeys (dark colored honeys) as compared to flower or thyme honeys, is in agreement with the results reported by Petretto et al. [17] for Moroccan dark colored honeys. It should also be mentioned that, undecanal and dodecanal were detected only in flower honeys from Samos Island.

Phenolic volatiles with sweet or honey like aroma such as benzaldehyde and benzeneacetaldehyde were identified in much higher proportions $(\mu \mathrm{g} / \mathrm{kg})$ in thyme honeys from Kos Island compared to flower honeys from Samos Island, whereas such compounds were absent in fir honeys from Aitolokarnania region. This observation may be indicative of both: botanical and geographical origin aspects. Benzaldehyde and benzeneacetaldehyde have been reported previously to enhance the volatile fraction of Italian [11], Spanish [5, 6], Hellenic [2,10], and Turkish thyme honeys [15].

Para-cymene (1-methyl-4-(1-methylethyl)-benzene) was identified at higher amounts $(\mu \mathrm{g} / \mathrm{g})$ in flower honey from Samos Island compared to thyme honey from Kos Island, whereas it was not detected in fir honey from Aitolokarnania. This compound has been reported previously to enhance the volatile pattern of Hellenic thyme honeys [2], whereas it was not identified in Spanish thyme or blossom honeys [6].

Benzenemethanol and benzeneethanol (or 2-phenylethanol) were identified only in thyme honeys from Kos Island. These compounds have been reported previously to enhance the volatile fraction of Spanish thyme honeys [6].

Hexanoic, octanoic, nonanoic, decanoic, dodecanoic, and tridecanoic acid ethyl esters were detected in high amounts $(\mu \mathrm{g} / \mathrm{kg})$ in flower honeys from Samos Island compared to thyme or fir honeys (Tables 1-3). However, formic acid ethyl ester, ethoxymethylene-propanedioic acid diethyl ester and benzene acetic acid ethyl ester (ethyl phenyl acetate) were detected only in thyme honeys from Kos Island. These ethyl ester derivatives have not been reported previously, to enhance the volatile pattern of Spanish thyme honeys $[5,6]$.

Beta-damascenone, a cyclic carotenoid derivative, was identified only in thyme honeys which conform to previous work involving Hellenic thyme honeys [2]. Furthermore, betadamascenone has been reported previously to enhance the volatile fraction of Spanish artisanal and eucalyptus honeys, respectively $[14,18]$. It is characterized by a fruity, spicy and typical honey aroma [14].

With respect to furan derivatives, 2,5-diethyltetrahydrofuran, 1-(2-furanyl)-ethanone, 3-phenyl-furan, and 2,5-dimethyl-3-ethyl-4-acetyl-furan were identified in the volatile fraction of thyme honeys from Kos Island, whereas dihydro-5-methyl-2(3H)-furanone was detected only in the volatile fraction of fir honeys from Aitolokarnania region.

Soria et al. [5] reported that dihydro-5-methyl-2(3H)furanone enhanced the volatile fraction of Spanish eucalyptus honey. Furan related compounds usually serve as indicators of heat treatment and storage conditions [11]. Similar compounds have been reported previously to contribute to the volatile profile of Italian [11] and Spanish thyme honeys [5, 6]. 
Isophorone related volatiles (i.e. 2,6,6-trimethyl-2cyclohexene-1,4-dione) were found in low amounts $(1.44 \mu \mathrm{g} /$ $\mathrm{kg}$ ) in flower honeys from Samos Island. These compounds have been reported previously to enhance the volatile fraction of Spanish [5, 6] and Hellenic thyme honeys [2].

Finally, carvacrol [2-methyl-5-(1-methylethyl) phenol], was detected only in the volatile fraction of thyme honeys from Kos Island. Carvacrol may not be considered as an undisputed volatile marker of thyme honey since it has been previously identified only in traces in the volatile fraction of Spanish thyme honeys [6], or it was absent in the volatile fraction of Italian thyme honeys [11]. However, this volatile compound may be indicative of thyme honey production area.

\section{VOCs in honey serving as a biomonitor of environmental pollution}

Honey could serve as a biomonitor of environmental pollution due to anthropogenic activities. Indeed, the use of SPME-GC/MS on the headspace aroma of honey may provide information regarding specific volatiles that are pollutants [12]. The average $\pm \mathrm{SD}$ values $(\mu \mathrm{g} / \mathrm{kg})$ of such compounds (data not shown) were: chloroform (5.86 \pm 1.52$)$, cyclohexane (5.96 \pm 6.87), benzyl chloride (5.60 \pm 5.89), and 1,1-dichloro-ethene $(1.20 \pm 0.95)$ for thyme honey from Kos Island; chloroform (6.59 \pm 4.41$)$, cyclohexane $(2.91 \pm$ $2.10)$ and 1,1 -dichloro-ethene $(3.76 \pm 2.46)$ for flower thyme from Samos Island. Finally, in fir honeys from Aitolokarnania 1-bromo-napthalene was determined at $2.17 \pm 3.06 \mu \mathrm{g} / \mathrm{kg}$. Probably, the use of aerosol containing these compounds, could led to its deposition on flowers around the plant [12]. It should be noted that such pollutants have not been yet regulated by the official authorities worldwide.

\section{Pigment content of Hellenic honeys}

Pigment content (mAU) of honey samples analyzed followed the order: fir $>$ flower $>$ thyme (Figure 2 and Table 4). As it can be observed, dark colored honeys such as fir, possess a higher pigment content compared to light colored or nectar honeys (flower and thyme honeys). This is in conformity with the results of Beretta et al. [8], Bertoncelj et al. [19] and Karabagias et al. [9]. It should also be noted, that these differences were statistically significant $(p<0.05)$, highlighting thus, the impact of floral source on pigment content of honey.

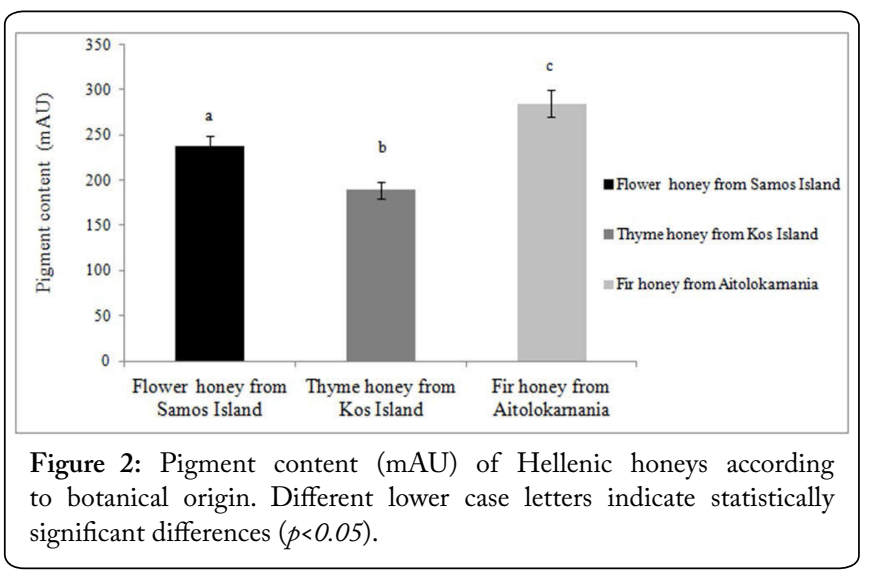

\section{Radical scavenging activity (\%RSA) of Hellenic honeys}

$\%$ RSA values of honey samples analyzed followed the order: fir > flower > thyme (Table 4). The capacity of an aqueous honey solution to reduce the activity of [DPPH$\left.{ }^{*}\right]$ free radical is shown in Figure 3. As in the case of pigment content, fir honeys recorded higher \%RSA values compared to flower or thyme honeys. This is also in agreement with previous work in the literature $[8,9,20,21]$.

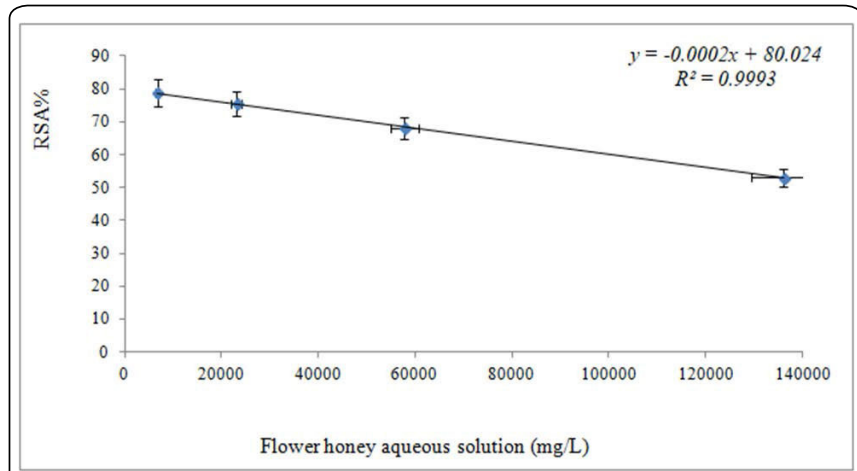

Figure 3: Radical scavenging activity (\%RSA) of flower honey aqueous solution from Samos Island.

Table 4: Pigment content and in vitro radical scavenging activity of flower, thyme, and fir honeys from Hellas.

\begin{tabular}{|l|l|c|c|}
\hline $\begin{array}{c}\text { Geographical } \\
\text { origin }\end{array}$ & \multicolumn{1}{|c|}{ Botanical origin } & $\begin{array}{c}\text { Pigment content } \\
(\mathbf{m A U})\end{array}$ & \%RSA \\
\hline Samos Island & Flower honey $(\mathrm{N}=7)$ & $237 \pm 31$ & $40.96 \pm 5.40$ \\
\hline Kos Island & Thyme honey $(\mathrm{N}=12)$ & $189 \pm 28$ & $25.30 \pm 9.47$ \\
\hline Aitolokarnania & Fir honey $(\mathrm{N}=2)$ & $285 \pm 52$ & $56.52 \pm 9.22$ \\
\hline
\end{tabular}

Average \pm standard deviation values of three measurements $(n=3)$. $\mathrm{N}$ : number of honey samples. Comparison of values using $\mathrm{T}$-test at the confidence level $p<0.05$.

An excellent Pearson's correlation $(r=1)$ was obtained between pigment content and \%RSA values of honey samples with respect to botanical origin $(p<0.01)$.

\section{Correlations between VOCs and \%RSA}

Pearson's correlation is defined by the coefficient $r$, which is an indicator of the degree of the linear relationship between two different parameters. A positive and high (close to 1) value of Pearson's correlation coefficient, adequately represents a linear relationship between the examined parameters. In that sense, the mean values of specific volatiles determined in flower vs. thyme, or thyme vs. fir honeys, were subjected to Pearson's correlation with their respective \%RSA values. These compounds were: alpha-pinene, p-cymene, delta-3-carene and 2-OH-BAME.

Perfect Pearson's correlation $(r=1)$ was obtained for the sets: a) alpha-pinene-\%RSA involving thyme and fir honeys (Tables 2-4), b) para-cymene-\%RSA involving flower and thyme honeys (Table 1, 2, and 4), c) delta-3-carene-\%RSA involving flower and thyme honeys (Tables 1, 2, and 4), and d) 2-OH-BAME$\%$ RSA involving thyme and fir honeys (Tables 2-4).

To the best of our knowledge, this is the first report in the literature about such correlation. 


\section{Conclusion}

Honey produced from different floral sources, may have definitely different aroma and taste, owed to differences in the volatile composition. VOCs not only contribute to the aroma of honey, but significantly influence the efforts on honey botanical and geographical origin identification. Information on the VOCs profile of honey, could aid in standardizing the quality of honey and contribute to its authenticity.

However, on the aforementioned efforts, specific geographical aspects including: weather conditions, soil fertilization and environmental purity, beekeepers practicing, honey extraction methods, etc., should be also considered.

In addition, the present study clearly demonstrates a strong impact of honey botanical origin on pigment content and radical scavenging activity $(p<0.05)$. To the best of our knowledge, this is the first report in the literature associating honey volatiles namely: alpha-pinene, delta-3-carene, p-cymene, and 2-hydroxy-benzoic acid methyl ester with antioxidant properties $(p<0.01)$.

Finally, this research was carried out in aqueous honey solutions and by using limited toxic solvents, providing thus, an eco-friendly scientific character.

\section{Conflict of Interest}

The authors declare that the research was conducted in the absence of any interests.

\section{Acknowledgments}

We thank Professor M.G. Kontominas who provided access to the Laboratory of Food Chemistry, Department of Chemistry, University of Ioannina, Greece.

\section{References}

1. Manyi-Loh CE, Ndip RN, Clarke AM. 2011. Volatile compounds in honey: a review on their involvement in aroma, botanical origin determination and potential biomedical activities. Int J Mol Sci 12(12): 9514-9532. https://doi.org/10.3390/ijms12129514

2. Karabagias IK, Badeka A, Kontakos S, Karabournioti S, Kontominas MG. 2014. Characterization and classification of Thymus capitatus (L.) honey according to geographical origin based on volatile compounds, physicochemical parameters and chemometrics. Food Res Int 55: 363372. https://doi.org/10.1016/j.foodres.2013.11.032

3. Al-Mamary M,Al-Meeri A, Al-Habori M. 2002. Antioxidant activities and total phenolics of different types of honey. Nutr Res 22(9): 10411047. https://doi.org/10.1016/S0271-5317(02)00406-2

4. Schramm DD, Karim M, Schrader HR, Holt RR, Cardetti M, et al. 2003. Honey with high levels of antioxidants can provide protection to healthy human subjects. J Agric Food Chem 51(6): 1732-1735. https:// doi.org/10.1021/jf025928k

5. Soria AC, Martínez-Castro I, Sanz J. 2008. Some aspects of dynamic headspace analysis of volatile components in honey. Food Res Int 41(8): 838-848. https://doi.org/10.1016/j.foodres.2008.07.010

6. Castro-Vázquez L, Díaz-Maroto MC, Perez-Coello MS. 2009. Differentiation of monofloral citrus, rosemary, eucalyptus, lavender, thyme, and heather honeys based on volatile composition and sensory descriptive analysis. Food Chem 112(4): 1022-1030. https://doi. org/10.1016/j.foodchem.2008.06.036
7. Brand-Williams W, Cuvelier ME, Berset C. 1995. Use of a free radical method to evaluate antioxidant activity. $L W T$ - Food Science and Technology 28(1): 25-30. https://doi.org/10.1016/S00236438(95)80008-5

8. Beretta G, Granata P, Ferrero M, Orioli M, Facino RM. 2005. Standardization of antioxidant properties of honey by a combination of spectrophotometric/fluorimetric assays and chemometrics. Anal Chim Acta 533(2): 185-191. https://doi.org/10.1016/j.aca.2004.11.010

9. Karabagias IK, Dimitriou E, Kontakos S, Kontominas MG. 2016. Phenolic profile, colour intensity, and radical scavenging activity of Greek unifloral honeys. Eur Food Res Technol 242(8): 1201-1210. https://doi.org/10.1007/s00217-015-2624-6

10. Alissandrakis E, Tarantilis PA, Pappas C, Harizanis PC, Polissiou M. 2009. Ultrasound-assisted extraction gas chromatography-mass spectrometry analysis of volatile compounds in unifloral thyme honey from Greece. Eur Food Res Technol 229(3): 365-373. https://doi. org/10.1007/s00217-009-1046-8

11. Piasenzotto L, Gracco L, Conte L. 2003. Solid phase microextraction (SPME) applied to honey quality control.J Sci Food Agric 83(10): 10371044. https://doi.org/10.1002/jsfa.1502

12. Bentivenga G, D’Auria, Fedeli P, Mauriello G, Racioppi R. 2004. SPME-GC-MS analysis of volatile organic compounds in honey from Basilicata. Evidence for the presence of pollutants from anthropogenic activities.Int J Food Sci Tech 39(10): 1079-1086.https://doi.org/10.1111/ j.1365-2621.2004.00889.x

13. Jerkovic' I, Mastelic' J, Marijanovic Z. 2006. A variety of volatile compounds as markers in unifloral honey from Dalmatian sage (Salvia officinalis L.). Chem Biodivers 3(12): 1307-1316. https://doi. org/10.1002/cbdv.200690134

14. Castro-Vázquez L, Díaz-Maroto MC, Guchu E, Perez-Coello MS. 2006. Analysis of volatile compounds of eucalypt honey by solid phase extraction followed by gas chromatography coupled to mass spectrometry. J Eur Food Res Technol 224(1): 27-31. https://doi. org/10.1007/s00217-006-0284-2

15. Mannas D, Altuğ T. 2007. SPME/GC/MS and sensory flavour profile analysis for estimation of authenticity of thyme honey. Int J Food Sci Tech 42(2): 133-138. https://doi.org/10.1111/j.1365-2621.2006.01157.x

16. Bayraktar D, Onoğur TA. 2011. Investigation of the aroma impact volatiles in Turkish pine honey samples produced in Marmaris, Datça and Fethiye regions by SPME/GC/MS technique. Int J Food Sci Tech 46(5): 1060-1065. https://doi.org/10.1111/j.1365-2621.2011.02588.x

17. Petretto GL, Tuberoso CIG, Vlahopoulou G, Atzei A, Mannu A, et al. 2016. Volatiles, color characteristics and other physico-chemical parameters of commercial Moroccan honeys. Nat Prod Res 30(3): 286292. https://doi.org/10.1080/14786419.2015.1056186

18. Soria AC, González M, de Lorenzo C, Martínez-Castro I, Sanz J. 2004. Characterization of artisanal honeys from Madrid (Central Spain) on the basis of their melissopalynological, physicochemical and volatile composition data. Food Chem 85(1): 121-130. https://doi.org/10.1016/j. foodchem.2003.06.012

19. Bertoncelj J, Dobersek U, Jamnik M, Golob T. 2007. Evaluation of the phenolic content, antioxidant activity and color of Slovenian honey. Food Chem 105(2): 822-828. https://doi.org/10.1016/j. foodchem.2007.01.060

20. Vela L, de Lorenzo C, Pérez RA. 2007. Antioxidant capacity of Spanish honeys and its correlation with polyphenol content and other physicochemical properties. J Sci Food Agric 87(6): 1069-1075. https:// doi.org/10.1002/jsfa.2813

21. Estevinho L, Pereira AP, Moreira L, Dias LG, Pereira E. 2008. Antioxidant and antimicrobial effects of phenolic compounds extracts of Northeast Portugal honey. Food Chem Toxicol 46(12): 3774-3779. https://doi.org/10.1016/j.fct.2008.09.062 